\title{
Surface and Subsurface Water Runoff and Selected Matter Components From the Forested Loess Slope
}

\author{
Andrzej Mazur ${ }^{1}$ \\ 1 University of Life Sciences in Lublin, Department of Environmental Engineering and Geodesy, ul. \\ Leszczyńskiego 7, 20-069 Lublin, Poland, e-mail: amazur70@op.pl
}

\begin{abstract}
In the years 2008-2011, the study on the surface and subsurface water runoff from the forested loess slope was carried out to determine the concentrations of selected chemical indicators of water quality, soil suspension and loss of the pure matter component. The maximum tested concentrations of water quality indicators were low and amounted to: $1.841 \mathrm{mg} \cdot \mathrm{dm}^{-3} \mathrm{~N}-\mathrm{Nog}, 0.943 \mathrm{mg} \cdot \mathrm{dm}^{-3} \mathrm{~N}^{-N_{4}}, 0.478 \mathrm{mg} \cdot \mathrm{dm}^{-3} \mathrm{~N}_{4} \mathrm{NO}_{3}, 0.213 \mathrm{mg} \cdot \mathrm{dm}^{-3} \mathrm{~N}^{-\mathrm{NO}_{2}}, 0.423 \mathrm{mg} \cdot \mathrm{dm}^{-3}$ $\mathrm{P}, 1.621 \mathrm{mg} \cdot \mathrm{dm}^{-3} \mathrm{~K}$. The masses of the eroded matter constituents were low and amounted to: $0.808 \mathrm{~kg} \cdot \mathrm{ha}^{-1} \mathrm{~N}$, $0.157 \mathrm{~kg} \cdot \mathrm{ha}^{-1} \mathrm{P}, 0.142 \mathrm{~kg} \cdot \mathrm{ha}^{-1} \mathrm{~K}$ and $2.989 \mathrm{~kg} \cdot \mathrm{ha}^{-1}$ soil. The parameters of erosive precipitation and water outflow were statistically significantly correlated with the concentration of soil suspended matter and losses of the analyzed components of matter, as well as negligible concentration of chemical indicators of water quality. Afforestation of the loess slopes threatened by erosion is a treatment that effectively protects the soil against water erosion.
\end{abstract}

Keywords: soil erosion, forest, surface and subsurface outflow, water quality, loess soil

\section{INTRODUCTION}

The soils developed from loess belong to the most fertile soils in the world [Catt 2001], but they are highly susceptible to soil erosion [Józefaciuk, Józefaciuk 1999]. Water erosion is a destructive process. Currently, it is considered one of the major soil degradation factors in the world. As a result of its operation, nutrients for plants and humus are leached from the soil [Lal 2005, Mazur 2018, Olson 2007], the physicochemical properties of soils deteriorate [Hladký et al. 2016, Ijaz et al. 2006], which leads to a decrease in their fertility [Duan et al. 2011, Lobo et al. 2005] and in the obtained crop yields [Arriaga, Lowery 2003, Papiernik et al. 2005]. The plant nutrients and soil material eroded from the fields [Mazur 2018], contribute to water eutrophication [Dupas et al. 2015, Gabryszewska et al. 2016, Grzywna et al. 2015] and silting of technical infrastructure devices [Asiedu 2018].

For many years, interdisciplinary research on soil erosion has been carried out. However, the studies covering the quantitative and qualitative surface and subsurface water runoff in the zone of eroded slopes, especially on forested slopes, are still poorly recognized and significantly less ac- centuated in the scientific literature [Mazur 2018, Święchowicz 2012, Żmuda 2006]. It has long been believed that the forest provides best protection for the soil against water erosion [Tyszka 2008], which does not mean that there is no soil erosion at all [Robichaud et al. 2010]. Therefore, it is necessary to strive for a better identification of the functioning of fluvial transport on the erosion-threatened forested areas, in order to rationally manage soil resources, in accordance with the principle of sustainable development.

The paper presents the results of research from 2008-2011, carried out under the conditions of a forested loess slope in the Lublin Upland, regarding the quantity and quality of surface and subsurface water runoff as well as selected components of matter.

\section{MATERIAL AND METHODS}

The research was carried out in the area of loess catchment with a periodic outflow of water in Wielkopole village, located in the eastern part of the Wyniosłość Giełczewska mesoregion (Lublin Upland) [Kondracki 2000]. The measure- 
ments of surface and subsurface outflows were carried out on a forested slope of $0.5 \mathrm{ha}$, with an average slope of about $11 \%$ and an NE exhibition. The slope was overgrown by a 13-year-old young tress pine (Pinus sylvestris L.) planted in a $1.5 \mathrm{x}$ $1.0 \mathrm{~m}$ rectangular spacing. The surface coverage was $100 \%$. The brushwood was not found, but few herbaceous plants grew in the undergrowth.

At the beginning of April 2008, a catcher of the surface runoff and subsurface outflows was installed in the lower part of the slope. The volume of outflowing water was measured and samples were taken for a laboratory analysis to determine: suspension, total nitrogen, ammonium nitrogen, nitrate nitrogen and nitrite nitrogen as well as phosphorus and potassium.

In April 2008, a soil research was carried out. A description of the soil profile was made, the soil samples were taken from the distinguished diagnostic horizon and the following parameters were determined: granulometric composition, density of the solid phase of the soil and soil bulk density, total porosity and water permeability coefficient.

The atmospheric precipitation in the basin was measured using a daily recording pluvograph and the Hellmann rain gauge. The meteorological station was established within the catchment area, about $400 \mathrm{~m}$ from the site of research. On the basis of pluvographs, the unit kinetic energy of rainfall and the erosive indicator of rain and surface runoff were calculated $-\mathrm{EI}_{30}$ index.

On the basis of the obtained research results, the dependences pertaining to the quality indicators of outflowing waters and losses of matter components on the parameters of precipitation and outflows were determined, based on the Pearson's linear $r_{x, y}$ correlation index, at a significance level of $\alpha=0.05$. A detailed description of the research methodology was given in the work of Mazur [2018].

\section{RESULTS AND DISCUSSION}

On the basis of the stratification of the distinguished diagnostic horizons made in the soil outcrop, in this study area the soils developed from loess and are of the lessive type (Haplic Luvisols). These are medium-eroded soils with an $\mathrm{O}-\mathrm{A}-\mathrm{B} 2 \mathrm{t}-\mathrm{BC}-\mathrm{Cca}$. The dominant fraction in the granulometric composition was dust, constituting about $62 \%$ (Table 1 ). The alluvial parts $(<0.02$ $\mathrm{mm}$ ) also constituted a high percentage (about $34 \%$ ), and a thick dusty loam constituted the largest share of these.

The average specific soil density was $2.6 \mathrm{Mg}$ $\mathrm{m}^{-3}$ and increased with depth (Table 2), as well as the bulk density, which ranged from 1.34 to 1.48 $\mathrm{Mg} \cdot \mathrm{m}^{-3}$. In contrast, the total porosity decreased with depth and fluctuated between 44.2 and $47.5 \%$. The water permeability coefficient also decreased with depth. Its highest value $\left(26.245 \cdot 10^{-6} \mathrm{~m} \cdot \mathrm{s}^{-1}\right)$ was recorded in the humus horizon.

The meteorological conditions have a very significant impact on the intensity of soil erosion [Żmuda 2006, Święchowicz 2012]. Their characteristics during the research period are presented in the publication of Mazur [2018]. The study

Table 1. Soil granulometric composition

\begin{tabular}{|c|c|c|c|c|c|c|c|c|}
\hline \multirow{2}{*}{ Horizon } & \multirow{2}{*}{$\begin{array}{c}\text { Depth } \\
{[\mathrm{cm}]}\end{array}$} & \multicolumn{6}{|c|}{ Percent of fraction of diameter [mm] } & \multirow{2}{*}{$\begin{array}{c}\text { Sum of floatable } \\
\text { parts }<0.02\end{array}$} \\
\hline & & $1-0.1$ & $0.1-0.05$ & $0.05-0.02$ & $0.02-0.006$ & $0.006-0.002$ & $<0.002$ & \\
\hline $\mathrm{O}$ & $0-4$ & - & - & - & - & - & - & - \\
\hline A & $4-17$ & 4.0 & 15.5 & 46.2 & 16.9 & 11.1 & 6.3 & 34.3 \\
\hline Bt2 & $17-48$ & 3.7 & 15.7 & 46.8 & 16.2 & 10.2 & 7.4 & 33.8 \\
\hline $\mathrm{BC}$ & $48-65$ & 2.9 & 16.5 & 45.9 & 16.5 & 9.8 & 8.4 & 34.7 \\
\hline Cca & $>65$ & 3.3 & 15.5 & 47.6 & 17.6 & 8.8 & 7.2 & 33.6 \\
\hline
\end{tabular}

Table 2. Selected physical properties of the studied soils

\begin{tabular}{|c|c|c|c|c|c|}
\hline Horizon & $\begin{array}{c}\text { Depth } \\
{[\mathrm{cm}]}\end{array}$ & $\begin{array}{c}\text { Specific density } \\
{\left[\mathrm{Mg} \cdot \mathrm{m}^{-3}\right]}\end{array}$ & $\begin{array}{c}\text { Bulk density } \\
{\left[\mathrm{Mg} \cdot \mathrm{m}^{-3}\right]}\end{array}$ & $\begin{array}{c}\text { Total porosity } \\
{[\%]}\end{array}$ & $\begin{array}{c}\text { Water permeability } \\
{\left[\mathrm{x} 10^{-6} \mathrm{~m} \cdot \mathrm{s}^{-1}\right]}\end{array}$ \\
\hline A & $4-17$ & 2.55 & 1.34 & 47.5 & 26.245 \\
\hline Bt2 & $17-48$ & 2.61 & 1.39 & 46.7 & 17.326 \\
\hline BC & $48-65$ & 2.62 & 1.42 & 45.8 & 14.547 \\
\hline Cca & $>65$ & 2.65 & 1.48 & 44.2 & 12.258 \\
\hline
\end{tabular}


of surface runoff on a forested slope was carried out in 9 periods, while the subsurface outflow in 7 measurement periods. Rainfall heights then varied from 31.5 to $63.6 \mathrm{~mm}$ (Table 3 ). The calculated coefficient of variation was $24.21 \%$ (Table 4 ) - an average variation [Mucha 1994]. Out of all the recorded instances of erosive precipitation, they occurred most frequently in July (55.6\%). In August, their incidence was $33.3 \%$, and in June $11.1 \%$.

The $\mathrm{EI}_{30}$ precipitation and surface runoff intensity index values ranged from 145.3 to 450.2 $\mathrm{MJ} \cdot \mathrm{mm} \cdot \mathrm{ha}^{-1} \cdot \mathrm{h}^{-1}$ (Table 4 ). The variation of the $\mathrm{EI}_{30}$ index amounted to $41.77 \%$ - high variation [Mucha 1994]. Dependence between the $\mathrm{EI}_{30}$ index and the total rainfall is shown in Figure 1. High precipitation erosion potential, expressed by the $\mathrm{EI}_{30}$ index, does not necessarily depend on the sum of the rainfall. The calculated value of the correlation coefficient between the $\mathrm{EI}_{30}$ index and the sum of rainfall $r=80$, indicates a very high correlation [Stanisz 1998]. The $\mathrm{R}^{2}$ determination index was 0.64 . The high dependence $\left(R^{2}=0.54\right)$ between the $\mathrm{EI}_{30}$ index and the amount of precipitation was also confirmed by the results obtained by Rejman [2006]. The correlation coefficient between $\mathrm{EI}_{30}$ and the precipitation height calculated by Święchowicz [2012] amounted to 0.51 .

The variation of surface water runoff from the slope was $79.75 \%$, indicating high variability [Mucha 1994]. The surface water runoff level on the slope was from 0.11 to $2.84 \mathrm{~mm}$ (Table 4), which constituted from 0.3 to $4.5 \%$ of the precipitation causing the erosive event. These are low rates in relation to the maximum surface outflows on arable lands, which can account for even more than $40 \%$ of precipitation causing the ero-

Table 3. Date of occurrence and amount of erosive precipitation: $a$ - surface runoff, $b$ - subsurface runoff

\begin{tabular}{|c|c|c|c|c|c|c|c|c|}
\hline \multirow[b]{2}{*}{ Month } & \multicolumn{2}{|c|}{2008} & \multicolumn{2}{|c|}{2009} & \multicolumn{2}{|c|}{2010} & \multicolumn{2}{|c|}{2011} \\
\hline & Date & $\begin{array}{c}\text { Rainfall } \\
{[\mathrm{mm}]}\end{array}$ & Date & $\begin{array}{c}\text { Rainfall } \\
{[\mathrm{mm}]}\end{array}$ & Date & $\begin{array}{c}\text { Rainfall } \\
{[\mathrm{mm}]}\end{array}$ & Date & $\begin{array}{c}\text { Rainfall } \\
{[\mathrm{mm}]}\end{array}$ \\
\hline Jun & - & - & $25(a, b)$ & 50.8 & - & - & - & - \\
\hline Jul & 7 (a) & 31.5 & - & - & $24(a, b)$ & 59.8 & $\begin{array}{c}3-4(a, b) \\
5(a, b) \\
20(a)\end{array}$ & $\begin{array}{l}63.5 \\
57.2 \\
32.1\end{array}$ \\
\hline Aug & - & - & - & - & $\begin{array}{c}6-7(a) \\
9(a, b) \\
30(a, b)\end{array}$ & $\begin{array}{l}44.2 \\
63.6 \\
41.5 \\
\end{array}$ & - & - \\
\hline
\end{tabular}

Table 4. Indicators characterizing rainfall, surface and subsurface runoff: a - surface runoff, $b$ - subsurface runoff

\begin{tabular}{|c|c|c|c|c|c|c|}
\hline \multicolumn{2}{|l|}{ Indicator } & Medium & $\begin{array}{l}\text { Standard } \\
\text { Deviation }\end{array}$ & Variation & Minimum & Maximum \\
\hline \multicolumn{2}{|l|}{ Rainfall [mm] } & 49.4 & 11.9 & 24.21 & 31.5 & 63.6 \\
\hline \multicolumn{2}{|c|}{ Kinetic energy $\left[\mathrm{J} \cdot \mathrm{h}^{-1}\right]$} & 491.7 & 153.4 & 31.19 & 245.3 & 699.3 \\
\hline \multicolumn{2}{|c|}{ Index $\mathrm{EI}_{30}\left[\mathrm{MJ} \cdot \mathrm{mm} \cdot \mathrm{ha}^{-1} \cdot \mathrm{h}^{-1}\right]$} & 277.7 & 115.9 & 41.77 & 145.3 & 450.2 \\
\hline \multirow{2}{*}{$\begin{array}{l}\text { Outflow } \\
{[\mathrm{mm}]}\end{array}$} & $\mathrm{a}$ & 1.27 & 1.01 & 79.75 & 0.11 & 2.84 \\
\hline & $\mathrm{b}$ & 0.05 & 0.02 & 30.38 & 0.03 & 0.08 \\
\hline \multirow{2}{*}{$\begin{array}{l}\text { Soil suspension } \\
{\left[\mathrm{g} \cdot \mathrm{dm}^{-3}\right]}\end{array}$} & $a$ & 0.033 & 0.02 & 53.77 & 0.012 & 0.059 \\
\hline & $\mathrm{b}$ & 0.018 & 0.01 & 30.39 & 0.011 & 0.025 \\
\hline \multirow{2}{*}{$\begin{array}{l}\text { N-Nog } \\
{\left[\mathrm{mg} \cdot \mathrm{dm}^{-3}\right]}\end{array}$} & $\mathrm{a}$ & 1.139 & 0.22 & 19.15 & 0.895 & 1.464 \\
\hline & $\mathrm{b}$ & 1.485 & 0.30 & 20.31 & 1.025 & 1.841 \\
\hline \multirow{2}{*}{$\begin{array}{l}\mathrm{N}-\mathrm{NH}_{4} \\
{\left[\mathrm{mg} \cdot \mathrm{dm}^{-3}\right]}\end{array}$} & $\mathrm{a}$ & 0.591 & 0.12 & 20.66 & 0.442 & 0.819 \\
\hline & $\mathrm{b}$ & 0.795 & 0.15 & 20.35 & 0.548 & 0.943 \\
\hline \multirow{2}{*}{$\begin{array}{l}\mathrm{N}-\mathrm{NO}_{3} \\
{\left[\mathrm{mg} \cdot \mathrm{dm}^{-3}\right]}\end{array}$} & a & 0.301 & 0.07 & 22.53 & 0.218 & 0.386 \\
\hline & $\mathrm{b}$ & 0.382 & 0.09 & 23.62 & 0.254 & 0.478 \\
\hline \multirow{2}{*}{$\begin{array}{l}\mathrm{N}-\mathrm{NO}_{2} \\
{\left[\mathrm{mg} \cdot \mathrm{dm}^{-3}\right]}\end{array}$} & $\mathrm{a}$ & 0.146 & 0.03 & 18.96 & 0.104 & 0.185 \\
\hline & $\mathrm{b}$ & 0.178 & 0.03 & 18.92 & 0.162 & 0.213 \\
\hline \multirow{2}{*}{$P\left[\mathrm{mg} \cdot \mathrm{dm}^{-3}\right]$} & $\mathrm{a}$ & 0.257 & 0.05 & 19.72 & 0.194 & 0.379 \\
\hline & $\mathrm{b}$ & 0.331 & 0.07 & 22.25 & 0.212 & 0.423 \\
\hline \multirow{2}{*}{$\mathrm{K}\left[\mathrm{mg} \cdot \mathrm{dm}^{-3}\right]$} & $a$ & 1.123 & 0.16 & 14.36 & 0.946 & 1.421 \\
\hline & $\mathrm{b}$ & 1.335 & 0.18 & 13.12 & 1.311 & 1.621 \\
\hline
\end{tabular}




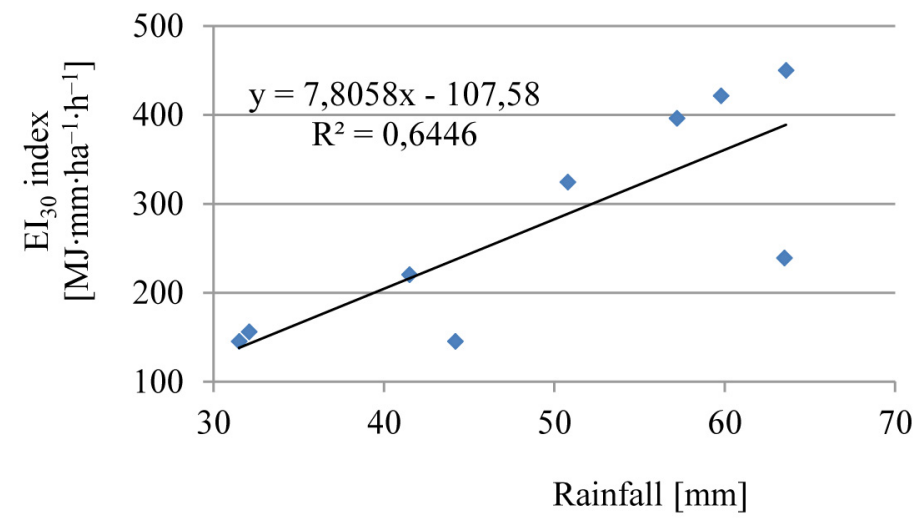

Fig. 1. Rainfall erosivity index $\mathrm{EI}_{30}$ in dependence on rainfall amount

sive event [Rejman 2006]. The subsurface runoff during the research period occurred only from the confined layer up to $0.25 \mathrm{~m}$. Their variation amounted to $30.38 \%$ - average variability [Mucha 1994].

The subsurface water outflows ranged from 0.03 to $0.08 \mathrm{~mm}$ (Table 4), which accounted for 0.07 and $0.13 \%$, respectively, of the precipitation causing the erosive event. In total, the largest outflows were recorded in 2010 (a wet year with precipitation of $867.7 \mathrm{~mm}$ ). The surface runoff was then $5.74 \mathrm{~mm}$, and the subsurface outflow was $0.17 \mathrm{~mm}$, which accounted for $0.66 \%$ and $0.02 \%$, of annual precipitation, respectively. Very low runoff rates are the result of the high retention capacity of forest ecosystems. According to a study conducted by Tyszka [2008], interception, retention of forest litter and a relatively high permeability of forest soils enable the retention of a large part of the precipitation and conversion of surface runoff into a vertical ground drain. Thus, the forest increases the resources of groundwater.

The concentration of the soil suspension contained in the surface runoff waters was characterized by high variability $(53.77 \%)$ and ranged from 0.012 to $0.059 \mathrm{~g} \cdot \mathrm{dm}^{-3}$, and in the subsurface runoff waters $0.011-0.025 \mathrm{~g} \cdot \mathrm{dm}^{-3}$ (Table 4 ). With respect to the concentrations of soil suspended in waters flowing from arable land reaching the maximum values of $170-240 \mathrm{~g} \cdot \mathrm{dm}^{-3}$ [Mazur 2018, Żmuda 2006], they should be recognized as very low. The mass of the eroded soil on the slope during individual events was also very low, from 0.01 to $1.67 \mathrm{~kg} \cdot \mathrm{ha}^{-1}$ during the surface runoff and 0.003 to $0.020 \mathrm{~kg} \cdot \mathrm{ha}^{-1}$ during the subsurface outflow. In the field of sugar beet cultivation, the maximum surface soil wash during a single event was estimated by Żmuda [2006] at $60.132 \mathrm{Mg} \cdot \mathrm{ha}^{-1}$ and
Rejman [2006] at $20.640 \mathrm{Mg} \cdot \mathrm{ha}^{-1}$ (cultivation of root crops). The surface wash of the soil from the forested slope during the four years of research was $5.390 \mathrm{~kg} \cdot \mathrm{ha}^{-1}$. The largest amount of the eroded soil $(54.8 \%)$ flowed in $2010\left(2.953 \mathrm{~kg} \cdot \mathrm{ha}^{-1}\right)$, and the lowest in $2008\left(0.013 \mathrm{~kg} \cdot \mathrm{ha}^{-1}\right.$ (Figure 2a). During the subsurface outflow, the mass of the eroded soil during the four-year study period was $0.066 \mathrm{~kg} \cdot \mathrm{ha}^{-1}$. The highest soil losses $(0.036$ $\mathrm{kg} \cdot \mathrm{ha}^{-1}$, which is $54.52 \%$ of the total eroded soil mass) were recorded in 2010, while the lowest $\left(0.008 \mathrm{~kg} \cdot \mathrm{ha}^{-1}\right)$ in 2009 (Figure 2b). In comparison with arable land, soil loss from the forested slope, should be considered as very low. According to the studies by Mazur [2018] and Rejman [2006], the annual soil losses on arable lands can even exceed $160 \mathrm{Mg} \cdot \mathrm{ha}^{-1}$.

The chemistry of waters flowing from the slope was characterized by low diversity. This is evidenced by the calculated values of variation coefficients ranging from 19.15 to $23.62 \%$ (Table 4) - small variability [Mucha 1994]. The concentration of total nitrogen in the surface flowing waters ranged from 0.895 to $1.464 \mathrm{mg} \cdot \mathrm{dm}^{-3} \mathrm{~N}-\mathrm{Nog}$. On the other hand, the concentrations of other forms of nitrogen were at the level of: ammonium 0.442$0.819 \mathrm{mg} \cdot \mathrm{dm}^{-3} \mathrm{~N}^{-N_{4}}$, nitrate $0.28-0.386 \mathrm{mg} \cdot \mathrm{dm}^{-3}$ $\mathrm{N}-\mathrm{NO}_{3}$, nitrite $0.104-0.185 \mathrm{mg} \cdot \mathrm{dm}^{-3} \mathrm{~N}-\mathrm{NO}_{2}$. The concentration of phosphorus flowing away in the dissolved form was in the range of 0.194-0.379 $\mathrm{mg} \cdot \mathrm{dm}^{-3} \mathrm{P}$, and potassium $0.946-1.421 \mathrm{mg} \cdot \mathrm{dm}^{-3}$ $\mathrm{K}$. In the subsurface flowing waters, total nitrogen concentrations ranged from 1.025 to 1.841 $\mathrm{mg} \cdot \mathrm{dm}^{-3} \mathrm{~N}-\mathrm{Nog}$. The concentrations of other forms of nitrogen were at the level of: ammonium $0.548-0.943 \mathrm{mg} \cdot \mathrm{dm}^{-3} \mathrm{~N}^{-\mathrm{NH}_{4}}$, nitrate $0.254-0.478$ $\mathrm{mg} \cdot \mathrm{dm}^{-3} \quad \mathrm{~N}-\mathrm{NO}_{3}$, nitrite $0.162-0.213 \mathrm{mg} \cdot \mathrm{dm}^{-3}$ $\mathrm{N}-\mathrm{NO}_{2}$. The concentration of phosphorus was on the level of $0.212-0.423 \mathrm{mg} \cdot \mathrm{dm}^{-3} \mathrm{P}$, and potas- 
a)



b)

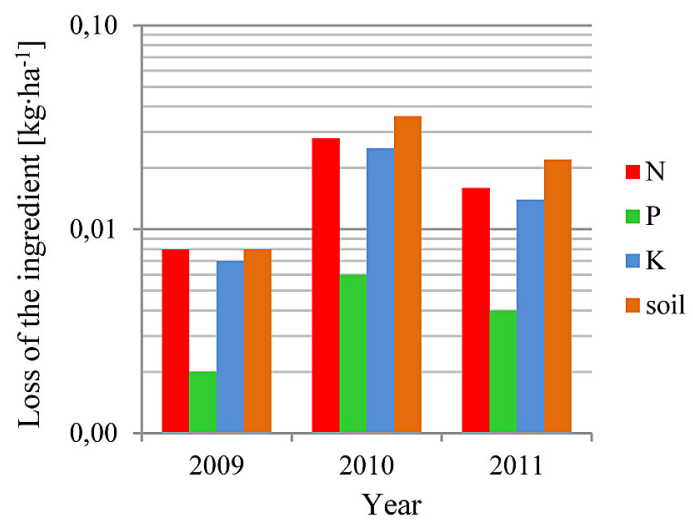

Fig. 2. Losses of N, P, K and soil as a result of surface (a) and subsurface (b) runoff from the slope

sium $1.311-1.621 \mathrm{mg} \cdot \mathrm{dm}^{-3} \mathrm{~K}$. It is worth noting that only in the case of ammonium nitrogen and phosphorus, the maximum concentration exceeded the limit values for the I class of water purity established in the Regulation of the Minister of Environment of November 9, 2011 [Reg... 2011]. The maximum concentrations of the remaining water quality indicators tested were at a low level and did not exceed the limit values of indicators for the first class of water purity.

The average annual concentration of the tested water quality index was varied in individual years of research, both in the surface (Figure 3a) and in subsurface water runoff (Figure $3 b$ ). In the surface outflow, the difference between the minimum, maximum and average annual concentrations of the tested indicator was at the level of 14 to $308 \%$. The least diverse (14-22\%) was the average annual concentration of $\mathrm{N}-\mathrm{NO}_{2}, \mathrm{P}$ and $\mathrm{K}$. For N-Nog and $\mathrm{N}_{-} \mathrm{NH}_{4}$, the difference was 40 and $41 \%$, respectively. However, for $\mathrm{N}^{-\mathrm{NO}_{3}}$ it was $77 \%$, and for soil suspension as much as $308 \%$. A smaller variation in average annual concentrations occurred in the subsurface outflow waters (12-40\%). For N-Nog, $\mathrm{K}$ and $\mathrm{N}-\mathrm{NO}_{3}$ the difference was from 12 to $14 \%$. For the soil suspension, $\mathrm{N}-\mathrm{NH}_{4}$ and $\mathrm{N}-\mathrm{NO}_{2}$ it amounted to $19,23,25 \%$, respectively. However, for $\mathrm{P}$ it was $40 \%$.

Together with water during surface runoff of waters, in a form dissolved from the forested slope, in the following year flowed: from 0.010 to $0.780 \mathrm{~kg} \cdot \mathrm{ha}^{-1} \mathrm{~N}-\mathrm{Nog}, 0.003-0.151 \mathrm{~kg} \cdot \mathrm{ha}^{-1} \mathrm{P}$, $0.011-0.117 \mathrm{~kg} \cdot \mathrm{ha}^{-1} \mathrm{~K}$ (Figure 2a). During the subsurface outflow of water, in the dissolved form, it flowed annually: from 0.008 to $0.028 \mathrm{~kg} \cdot \mathrm{ha}^{-1} \mathrm{~N}$ Nog, 0.002-0.006 kg $\cdot \mathrm{ha}^{-1} \mathrm{P}, 0.007-0.025 \mathrm{~kg} \cdot \mathrm{ha}^{-1}$ $\mathrm{K}$ (Figure 2b). These are low losses in relation to $\mathrm{N}, \mathrm{P}, \mathrm{K}$ losses occurring on agriculturally used lands. Kim et al. [2018] determined that the nitrogen losses range from $5.63-13.97 \mathrm{~kg} \cdot \mathrm{ha}^{-1}$, and the phosphorus losses from $0.96-11.00 \mathrm{~kg} \cdot \mathrm{ha}^{-1}$. However, according to Mazur's research [2018], the annual nitrogen losses range from 5.762 to 23.448 $\mathrm{kg} \cdot \mathrm{ha}^{-1}$, phosphorus from 0.696 to $4.644 \mathrm{~kg} \cdot \mathrm{ha}^{-1}$, and potassium from 5.937 to $19.216 \mathrm{~kg} \cdot \mathrm{ha}^{-1}$.

The calculated low values of Pearson's correlation coefficients enable to conclude that the concentration of the tested chemical indicator of water quality cannot be inferred from the parameters of erosive rainfall (its height, kinetic energy and $\mathrm{EI}_{30}$ index) or the size of water outflow. The analysis of the dependence, at the significance level of $\alpha=0.05$, did not show any statistically significant correlations between the analyzed factors (Table 5), both for surface and subsurface flowing waters - correlations from faint to weak [Stanisz 1998]. The statistically significant dependencies were obtained between the precipitation parameters as well as the surface and subsurface outflows (correlations from high to almost certain [Stanisz 1998]). Additionally, the soil suspension concentrations, as well as soil losses, N, P and $\mathrm{K}$ were in most cases significantly statistically correlated with precipitation erosive rainfall and the size of the water outflow (correlations from high to almost certain [Stanisz 1998]).

\section{CONCLUSIONS}

The research carried out on the forested loess slope, on the outflow of surface and subsurface water and selected components of matter, prove that this is an area threatened by erosion, and the flowing waters are laden with chemical and me- 
a)

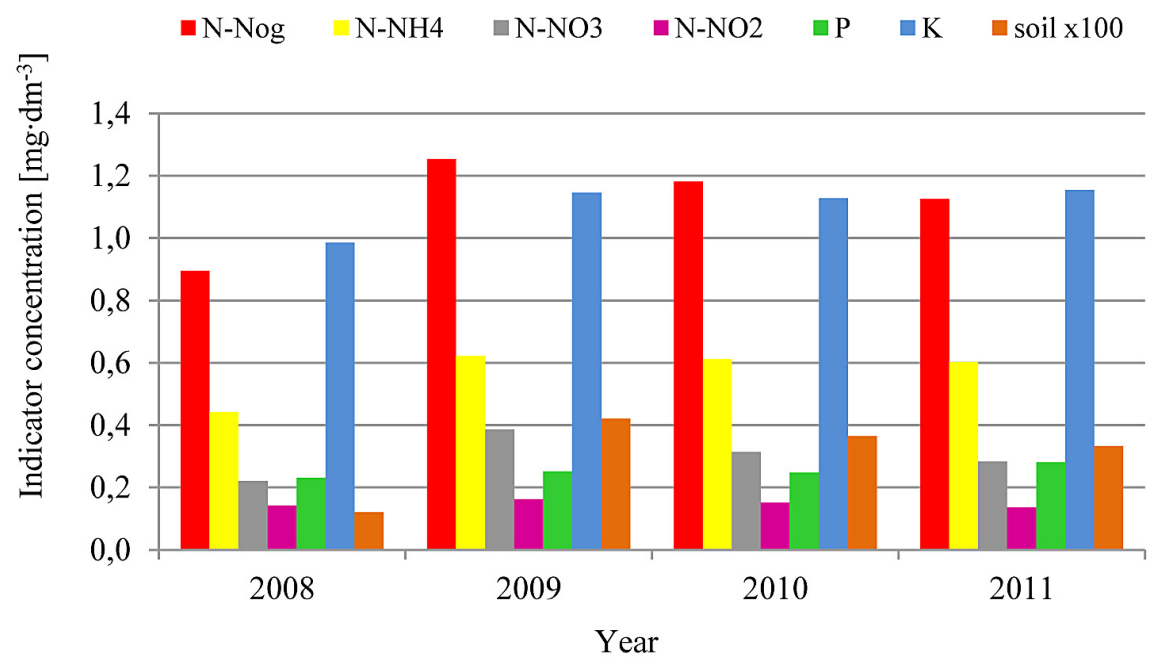

b)

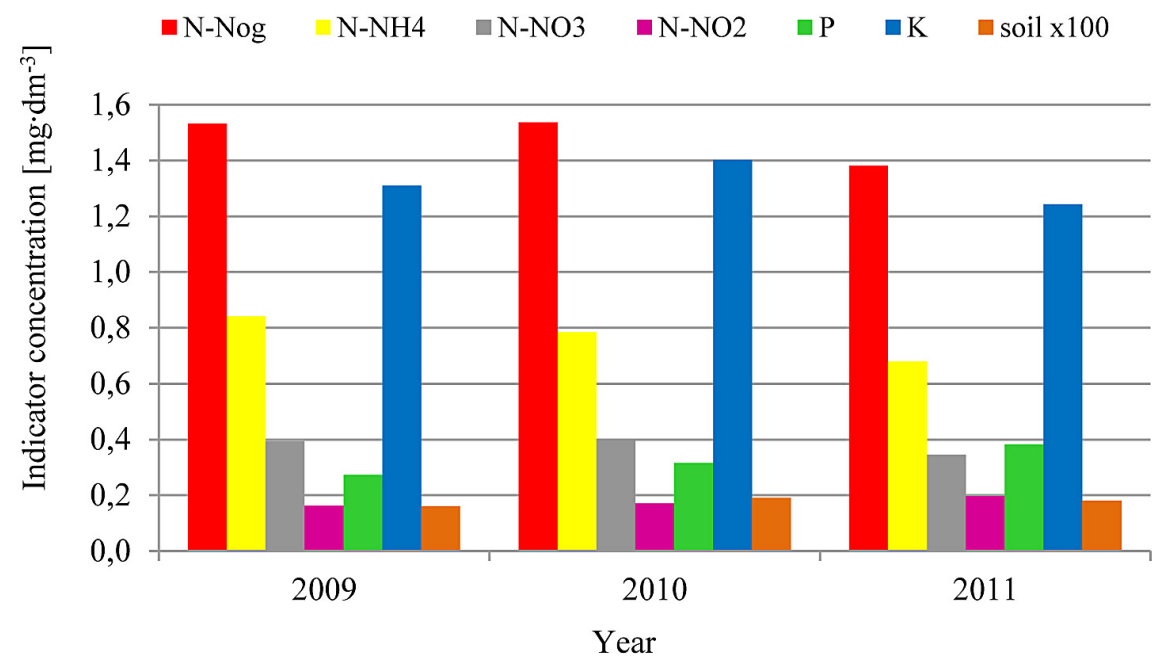

Fig. 3. Average annual concentration of tested indicators of water quality in surface (a) and subsurface (b) runoff from forested slope

chanical pollution. This is the result of the denuding processes. However, the losses of N, P, K and soil are low in relation to the losses recorded on arable lands. The following conclusions can be drawn on the basis of the research:

The surface runoffs from the slopes were at a low level of 0.11 to $2.84 \mathrm{~mm}$, representing 0.3 to $4.5 \%$ of the precipitation causing the erosive event. The subsurface outflows occurred only from the layer up to $0.25 \mathrm{~m}$ and ranged from 0.03 to $0.08 \mathrm{~mm}$, which accounted for 0.07 and $0.13 \%$, of erosive precipitation, respectively.

The maximum concentrations of ammonium nitrogen and phosphorus in the waters flowing from the slope exceeded the limit values for the class I water purity and were: $0.943 \mathrm{mg} \cdot \mathrm{dm}^{-3}$ $\mathrm{N}-\mathrm{NH}_{4}, 0.423 \mathrm{mg} \cdot \mathrm{dm}^{-3} \mathrm{P}$, respectively. In contrast, the maximum concentrations of the other quality indicators tested water (total nitrogen, ammonium and nitrite, potassium and slurry) were at a low level and did not exceed the limit values for class I water purity.

The maximum annual losses of plant nutrients and soil were: $0.808 \mathrm{~kg} \cdot \mathrm{ha}^{-1} \mathrm{~N}, 0.157 \mathrm{~kg} \cdot \mathrm{ha}^{-1}$ $\mathrm{P}, 0.142 \mathrm{~kg} \cdot \mathrm{ha}^{-1} \mathrm{~K}$ and $2.989 \mathrm{~kg} \cdot \mathrm{ha}^{-1}$ soil.

There were no statistically significant relationships between the concentration of the tested chemical indicator of water quality and erosive precipitation and its parameters. water outflow, a concentration of soil suspension, soil losses and $\mathrm{N}, \mathrm{P}, \mathrm{K}$ were significantly correlated with erosive precipitation and its parameters. High correlation was also obtained between water outflow and soil suspension concentration as well as soil losses, $\mathrm{N}, \mathrm{P}$ and $\mathrm{K}$.

Afforestation of the loess slopes threatened by erosion is a treatment that effectively protects the soil against water erosion, as well as surface waters against eutrophication, due to the low level of leaching of biogenic elements. 
Table 5. Correlation between the quality indicators of outflowing waters and losses of constituents of matter, precipitation parameters and outflow

\begin{tabular}{|c|c|c|c|c|c|}
\hline \multicolumn{2}{|c|}{ Indicator } & \multirow{2}{*}{$\frac{\text { Rainfall [mm] }}{0.898^{*}}$} & \multirow{2}{*}{$\begin{array}{c}\begin{array}{c}\text { Kinetic energy } \\
{\left[\mathrm{J} \cdot \mathrm{h}^{-1}\right]}\end{array} \\
0.875^{*}\end{array}$} & \multirow{2}{*}{$\begin{array}{c}\begin{array}{c}\text { Index } \mathrm{El}_{30} \\
{\left[\mathrm{MJ} \cdot \mathrm{mm} \cdot \mathrm{ha}^{-1} \cdot \mathrm{h}^{-1}\right]}\end{array} \\
0.948^{*}\end{array}$} & \multirow{2}{*}{$\frac{\text { Outflow }[\mathrm{mm}]}{1}$} \\
\hline Outflow & a & & & & \\
\hline [mm] & $\mathrm{b}$ & $0.678^{*}$ & $0.812^{*}$ & $0.951^{*}$ & 1 \\
\hline \multirow{2}{*}{$\begin{array}{l}\text { Soil suspension } \\
{\left[\mathrm{g} \cdot \mathrm{dm}^{-3}\right]}\end{array}$} & a & $0.878^{*}$ & $0.913^{*}$ & $0.983^{*}$ & $0.972^{*}$ \\
\hline & $\mathrm{b}$ & 0.535 & $0.739^{*}$ & $0.967^{*}$ & $0.981^{*}$ \\
\hline \multirow{2}{*}{$\begin{array}{l}\text { N-Nog } \\
{\left[\mathrm{mg} \cdot \mathrm{dm}^{-3}\right]}\end{array}$} & a & -0.148 & -0.195 & -0.254 & -0.142 \\
\hline & $b$ & -0.194 & -0.243 & -0.301 & -0.199 \\
\hline \multirow{2}{*}{$\begin{array}{l}\mathrm{N}-\mathrm{NH}_{4} \\
{\left[\mathrm{mg} \cdot \mathrm{dm}^{-3}\right]}\end{array}$} & a & -0.189 & -0.252 & -0.235 & 0.195 \\
\hline & $\mathrm{b}$ & -0.275 & -0.297 & -0.352 & -0.295 \\
\hline \multirow{2}{*}{$\begin{array}{l}\mathrm{N}-\mathrm{NO}_{3} \\
{\left[\mathrm{mg} \cdot \mathrm{dm}^{-3}\right]}\end{array}$} & a & -0.254 & -0.289 & -0.292 & -0.164 \\
\hline & $b$ & -0.312 & -0.398 & -0.324 & -0.253 \\
\hline \multirow{2}{*}{$\begin{array}{l}\mathrm{N}-\mathrm{NO}_{2} \\
{\left[\mathrm{mg} \cdot \mathrm{dm}^{-3}\right]}\end{array}$} & a & -0.325 & -0.381 & -0.415 & -0.299 \\
\hline & $\mathrm{b}$ & -0.392 & -0.465 & -0.451 & -0.354 \\
\hline \multirow{2}{*}{$P\left[\mathrm{mg} \cdot \mathrm{dm}^{-3}\right]$} & a & -0.256 & -0.251 & -0.245 & -0.189 \\
\hline & $\mathrm{b}$ & -0.323 & -0.359 & -0.321 & -0.256 \\
\hline \multirow{2}{*}{$\mathrm{K}\left[\mathrm{mg} \cdot \mathrm{dm}^{-3}\right]$} & a & -0.199 & -0.342 & -0.235 & -0.195 \\
\hline & $b$ & -0.232 & -0.389 & -0.298 & -0.248 \\
\hline \multirow{2}{*}{ Soil $\left[\mathrm{kg} \cdot \mathrm{ha}^{-1}\right]$} & a & $0.835^{*}$ & $0.861^{*}$ & $0.955^{*}$ & $0.983^{*}$ \\
\hline & $\mathrm{b}$ & 0.566 & $0.731^{*}$ & $0.942^{*}$ & $0.991^{*}$ \\
\hline \multirow{2}{*}{ N-Nog $\left[\mathrm{kg} \cdot \mathrm{ha}^{-1}\right]$} & a & $0.864^{*}$ & $0.875^{*}$ & $0.964^{*}$ & $0.993^{*}$ \\
\hline & $b$ & 0594 & $0.813^{*}$ & $0.974^{*}$ & $0.992^{*}$ \\
\hline \multirow{2}{*}{$P\left[\mathrm{~kg} \cdot \mathrm{ha}^{-1}\right]$} & a & $0.803^{*}$ & $0.788^{*}$ & $0.907^{*}$ & $0.956^{*}$ \\
\hline & $b$ & 0.665 & $0.743^{*}$ & $0.790^{*}$ & $0.927^{*}$ \\
\hline \multirow{2}{*}{$\mathrm{K}\left[\mathrm{kg} \cdot \mathrm{ha}^{-1}\right]$} & a & $0.841^{*}$ & $0.845^{*}$ & $0.945^{*}$ & $0.990^{*}$ \\
\hline & $\mathrm{b}$ & 0.599 & $0.790^{*}$ & $0.954^{*}$ & $0.987^{*}$ \\
\hline
\end{tabular}

Comments:

* statistically significant.

$\mathrm{a}$ - surface runoff, $\mathrm{b}$ - subsurface runoff.

\section{Acknowledgements}

Publication supported by the Polish Ministry of Science and Higher Education as a part of the program of activities disseminating science from the project „Organization of the First International Science Conference - Ecological and Environmental Engineering”, 26-29 June 2018, Kraków.

\section{REFERENCES}

1. Arriaga F.J., Lowery B. 2003. Corn production on an eroded soil: effects of total rainfall and soil water storage. Soil and Till. Res., 71, 87-93.

2. Asiedu J.K. 2018. Assessing the Threat of Erosion to Nature-Based Interventions for Stormwater Management and Flood Control in the Greater Accra Metropolitan Area, Ghana. Journal of Ecological Engineering, 19(1), 1-13.
3. Catt J.A. 2001. The agricultural importance of loess. Earth-Sci. Reviews, 54, 213-229.

4. Duan X., Xie Y., Ou T., Lu H. 2011. Effects of soil erosion on long-term soil productivity in the black soil region of northeastern China. Catena, 87, 268-275.

5. Dupas R., Delmas M., Dorioz J.M., Garnier J., Moatar F., Gascuel-Odoux C. 2015. Assessing the impact of agricultural pressures on $\mathrm{N}$ and $\mathrm{P}$ loads and eutrophication risk. Ecol. Indic., 48, 396-407.

6. Gabryszewska M., Kucharczak K., Maciaszek D., Gworek B., Kijeńska M., Tokarz L. 2016. The computational models for determining predicted substance concentrations in surface waters. Przem. Chem., 95/3, 609-612 (in Polish).

7. Grzywna A., Tarkowska-Kukuryk M., Bochniak A., Marczuk A., Jóźwiakowski K., Marzec M., Mazur A., Obroślak R., Nieścioruk K., Zarajczyk J. 2015. Application of chemical and biological indicators for assessment of an ecological potential 
of artificial watercourses. Przem. Chem., 94/11, 1954-1957 (in Polish).

8. Hladký J., Novotná J., Elbl J., Kynický J., Juřička D., Novotná J., Brtnický M., 2016. Impacts of Water Erosion on Soil Physical Properties Acta Univ. Agric. Silvic. Mendelianae Brun., 64, 1523-1527.

9. Ijaz A., Khan F., Bhatti A.U. 2006. Some physicochemical properties of soil as influenced by surface erosion under different cropping systems on upland-sloping soil. Soil and Environ., 25(1), 28-34.

10. Józefaciuk A., Józefaciuk Cz. 1999. Mechanism and methodical guidelines for the study of erosion processes. PIOŚ, Bibl. Monit. Środ. (in Polish).

11. Kondracki J. 2000. Regional geography of Poland. Wyd. Nauk. PWN (in Polish).

12. Kim K., Kim B., Eum J., Seo B., Christopher L., Shope C.L., Peiffer S. 2018. Impacts of land use change and summer monsoon on nutrients and sediment exports from an agricultural catchment. Water, 10, 544, doi:10.3390/w10050544.

13. Lal R. 2005. Soil erosion and carbon dynamics. Soil Till. Res., 81,137-142.

14. Lobo D., Lozano Z., Delgado F. 2005. Water erosion risk assessment and impact on productivity of a Venezuelan soil. Catena, 64, 297-306.

15. Mazur A. 2018. Quantity and Quality of Surface and Subsurface Runoff from an Eroded Loess Slope Used for Agricultural Purposes. Water, 10, 1132, doi:10.3390/w10091132.

16. Mucha J. 1994. Geostatistical methods in documenting deposits. Skrypt Katedry Geologii Kopalnianej AGH (in Polish).
17. Olson K.R. 2007. Soil organic carbon storage in southern Illinois woodland and cropland. Soil Sci., 172, 623-630.

18. Papiernik S.K., Lindstrom M.J., Schumacher J.A., Farenhorst A., Stephens K.D., Schumacher T.E., Lobb D.A. 2005. Variation in soil properties and crop yield across an eroded prairie landscape. J. Soil Water Conserv., 60, 388-395.

19. Regulation of the Minister of Environment of November 9, 2011 on the method of classification of uniform state surface water bodies and environmental quality standards for priority substances. Dz. U. 2011. nr 257 poz. 1545 (in Polish).

20. Rejman J. 2006. Effect of water and tillage erosion on transformation of soils and loess slopes. Acta Agroph., 136 (in Polish).

21. Robichaud P. R., Wagenbrenner J. W., Brown R. E. 2010. Rill erosion in natural and disturbed forests: 1. Measurements. Water Resources Research, 46, W10506.

22. Stanisz A. 1998. An affordable statistics course. Vol. 1. StatSoft Polska Sp. z o.o. Kraków (in Polish).

23. Święchowicz J. 2012. Rainfall thresholds for erosion processes in agricultural catchments. Wyd. IGiGP UJ, Kraków (in Polish).

24. Tyszka J. 2008. Hydrological functions of forests in small lowland catchments. Prace IBL Rozprawy i Monografie, 10 (in Polish).

25. Żmuda R. 2006. Fluvial transport system functioning in small catchment threatened by soil water erosion. Zesz. Nauk. AR we Wrocławiu, 544 (in Polish). 